\title{
Metallohelices with activity against cisplatin-resistant cancer cells; does the mechanism involve DNA binding? $\uparrow$
}

\author{
Viktor Brabec, ${ }^{\text {,b }}$ Suzanne E. Howson, ${ }^{a}$ Rebecca A. Kaner, ${ }^{a}$ Rianne M. Lord, ${ }^{c}$ \\ Jaroslav Malina, ${ }^{b}$ Roger M. Phillips, ${ }^{d}$ Qasem M. A. Abdallah, ${ }^{d}$ Patrick C. McGowan, ${ }^{c}$ \\ Alison Rodger ${ }^{a}$ and Peter Scott ${ }^{\star a}$
}

Enantiomers of a relatively rigid DNA-binding metallo-helix are shown to have comparable activity to that of cisplatin against the cell lines MCF7 (human breast adenocarcinoma) and A2780 (human ovarian carcinoma) but are ca five times more active against the cisplatin-resistant A2780cis. The cell-line HCT116 $\mathrm{p53}^{+/+}$(human colon carcinoma) is highly sensitive giving $\mathrm{IC}_{50}$ values in the $\mathrm{nM}$ range, far lower than the cisplatin control. The hypothesis that the biological target of such metallohelices is DNA is probed by various techniques. Tertiary structure changes in ct-DNA (formation of loops and intramolecular coiling) on exposure to the compounds are demonstrated by atomic force microscopy and supported by circular/linear dichroism in solution. Selectivity for 5'-CACATA and 5'-CACTAT segments is shown by DNase I footprinting. Various three- and four-way oligonucleotide junctions are stabilised, and remarkably only the $\Lambda$ metallo-helix enantiomer stabilizes T-shaped 3WJs during gel electrophoresis; this is despite the lack of a known helix binding site. In studies with oligonucleotide duplexes with bulges it is also shown for the first time that the metallo-helix binding strength and the number of binding sites are dependent on the size of the bulge. In contrast to all the above, flexible metallo-helices show little propensity for structured or selective DNA binding, and while for A2780 the cancer cell line cytotoxicity is retained the A2780cis strain shows significant resistance. For all

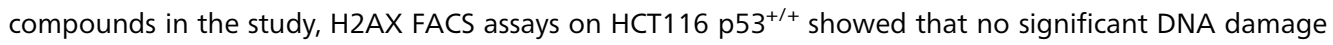
occurs. In contrast, cell cycle analysis shows that the DNA binders arrest cells in the G2/mitosis phase, and while all compounds cause apoptosis, the DNA binders have the greater effect. Taken together these screening and mechanistic results are consistent with the more rigid helices acting via a DNA binding mechanism while the flexible assemblies do not.

Received 20th June 2013

Accepted 29th August 2013

DOI: $10.1039 /$ c3sc51731d

www.rsc.org/chemicalscience

\section{Introduction}

Clinical anticancer treatments commonly include the use of DNA-binding or -modifying drugs. Alkylators and DNA cleavage agents cause chemically irreversible reactions leading, in the absence of repair, to cell death, ${ }^{\mathbf{1 , 2}}$ whereas DNA groove-binders and intercalators form non-covalent bonds, commonly affecting replication and transcription. ${ }^{3,4}$ Coordination chemistry plays an important role in both these areas; ${ }^{5,6}$ cisplatin chemotherapy is a resurgent field of research ${ }^{7-9}$ and metal scaffolds are being

${ }^{a}$ Department of Chemistry, University of Warwick, Gibbet Hill Road, Coventry, CV4 7AL, UK. E-mail: peter.scott@warwick.ac.uk; Fax: +44 (0)24 7657 2710; Tel: +44 (0) 2476523238

${ }^{b}$ Institute of Biophysics, Academy of Sciences of the Czech Republic, v.v.i., Královopolská 135, CZ-61265 Brno, Czech Republic. E-mail: brabec@ibp.cz ${ }^{c}$ School of Chemistry, University of Leeds, Woodhouse Lane, Leeds, LS2 9JT, UK ${ }^{d}$ Institute of Cancer Therapeutics, University of Bradford, Bradford, BD7 1DP, UK $\dagger$ Electronic supplementary information (ESI) available: Experimental details for AFM imaging, DNA binding studies using CD and LD, DNase I footprinting, UV melting experiments and anticancer testing. See DOI: 10.1039/c3sc51731d used to explore regions of biologically relevant chemical space inaccessible to organic chemistry alone..$^{10-13}$

One such architecture is provided by metal-templated helicates $^{14-19}$ (Fig. 1, upper). These molecules commonly comprise three relatively rigid ditopic ligands such as the NN-NN system $\mathrm{I}^{20}$ wrapped in a helical array around two metal ions. The ligand

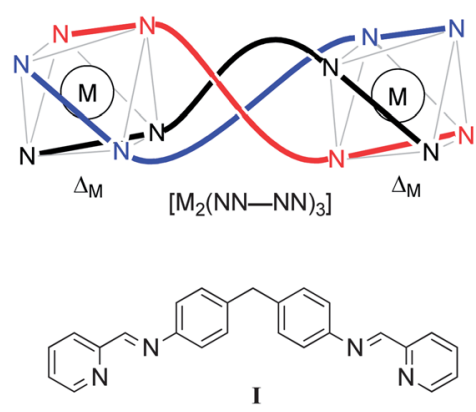

Fig. 1 Schematic representation (upper) of one enantiomer of a bimetallic triple-stranded metallo-helicate incorporating a NN-NN bis(bidentate) helicand. 
(referred to as a helicand) mechanically couples ${ }^{21}$ the helicity at the two metal centres such that they have the same absolute configuration $(\Delta$ or $\Lambda$ ). Their structural novelty has encouraged testing in the healthcare arena e.g. towards diagnostic applications ${ }^{22-29}$ but there are rather few metallo-helix systems that lend themselves to projects in drug discovery. ${ }^{19}$

Hannon's tetracations $\left[\mathrm{M}_{2}(\mathrm{I})_{3}\right]^{4+}(\mathrm{M}=\mathrm{Fe}, \mathrm{Ru})$ have been preeminent because of their simplicity and solubility, ${ }^{30}$ and despite their requirement for chromatographic resolution. They bind in the major groove of DNA with sequence-selectivity, ${ }^{31}$ induce intramolecular coiling ${ }^{32}$ and have some anticancer activity. ${ }^{33-35} \mathrm{Qu}$ has discovered that the same Fe compound recognises human telomeric G-quadruplex $\mathrm{DNA}^{36-38}$ and targets the amyloid $\beta$ peptide, reducing cytotoxicity and ameliorating memory deficits in a transgenic mouse model. ${ }^{39}$ Recently a derivative of $\left[\mathrm{Fe}_{2}(\mathbf{I})_{3}\right]^{4+}$ containing arginine units showed improved cytotoxicity against A2780 ovarian cancer cells. ${ }^{40}$

We recently developed optically and diastereochemically pure monometallic complexes containing functionalised pyridine/imine units ${ }^{\mathbf{4 1 4 2}}$ and then used them to create via selfassembly processes water stable, optically pure bimetallic structures with flexible linkers $\left[\mathrm{M}_{2} \mathrm{~L}_{3}\right]^{2+}$ (Fig. 2). ${ }^{43}$ Since the stereoselectivity in these complexes does not rely on the helicate concept of mechanical coupling we describe them as flexicates, ${ }^{43}+$ although in other instances mechanical coupling is important. ${ }^{\mathbf{4 4}}$ We also reported their promising antibiotic activity against MRSA (Methicillin-resistant Staphylococcus aureus) and Escherichia coli alongside modest toxicity towards the nematode worm Caenorhabditis elegans. ${ }^{43}$ In this work we describe the discovery of structure-dependent activity of flexicates against cancer cell-lines, including a cisplatin-resistant strain, and address the interactions of these compounds with potential drug targets in DNA and DNA-motifs via a range of biophysical techniques relevant to mechanism of action. ${ }^{45}$ In
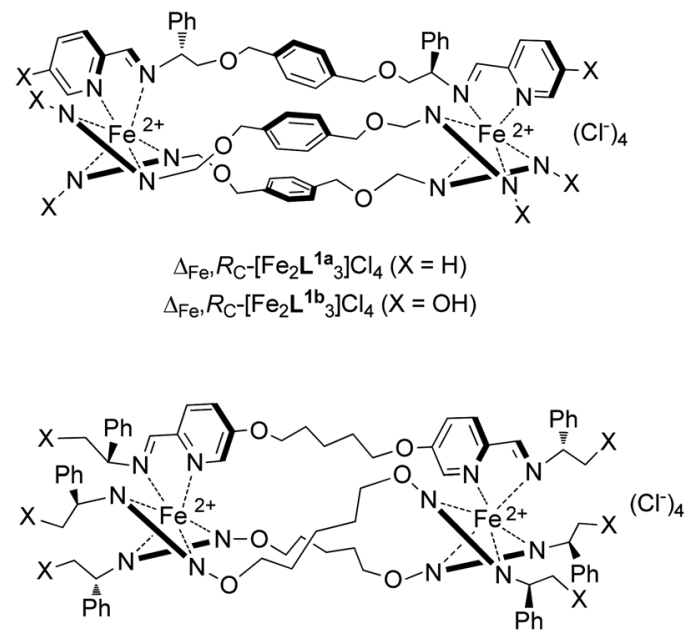

$$
\begin{gathered}
\Delta_{\mathrm{Fe}^{-}}-\left[\mathrm{Fe}_{2} \mathrm{~L}^{2 \mathrm{a}_{3}}\right] \mathrm{Cl}_{4}(\mathrm{X}=\mathrm{H}) \\
\Delta_{\mathrm{Fe}}-\left[\mathrm{Fe}_{2} \mathrm{~L}^{2 \mathrm{~b}}{ }_{3}\right] \mathrm{Cl}_{4}(\mathrm{X}=\mathrm{OH})
\end{gathered}
$$

Fig. 2 Diastereomerically pure metallo-helical "flexicate" complexes of chiral ligands $\mathrm{L}^{1}$ and $\mathrm{L}^{2}$. addition we probe the effects on cells via assay of DNA damage and cell-cycle analysis.

\section{Results and discussion}

\section{Cancer cell-line activity}

The absence of reactive metal centres in the helicates $\left[\mathrm{M}_{2}(\mathbf{I})_{3}\right]^{4+}$ (Fig. 1) described above means that a cisplatin-like lesion process is unlikely to be responsible for their cancer cell line cytotoxicity, yet it has been hypothesised that DNA binding is involved in the mechanism. ${ }^{33-35}$ The flexicate compounds $\left[\mathrm{Fe}_{2} \mathrm{~L}_{3}\right]^{4+}$ (Fig. 2) present an interesting series in this respect; linear dichroism studies indicate that while $\left[\mathrm{Fe}_{2} \mathbf{L}_{3}^{\mathbf{1 a}}\right]^{4+}$ binds to the major groove of calf thymus DNA, the system $\left[\mathrm{Fe}_{2} \mathbf{L}_{3}^{2 \mathbf{a}}\right]^{4+}$ does not. We thus set out to investigate the activity of the water soluble flexicates in cancer cell lines; MCF7 (human breast adenocarcinoma), A2780 (human ovarian carcinoma), the cisplatin resistant strain A2780cis and HCT116 p53 ${ }^{+/+}$(human colon carcinoma). In preliminary tests it was found that solutions of $\left[\mathrm{Fe}_{2} \mathbf{L}_{3}^{\mathbf{1 b}}\right] \mathrm{Cl}_{4}$ deposited solid complex under assay conditions and so our studies were confined to the remaining six compounds (three pairs of enantiomers) containing $\mathbf{L}^{\mathbf{1 a}}, \mathbf{L}^{\mathbf{2 a}}$ and $\mathbf{L}^{\mathbf{2 b}}$. The free ligands and major components were insufficiently soluble in DMSO/water for testing.

The flexicates show promising anticancer properties with a range of $\mathrm{IC}_{50}$ values from $c a 0.6-20 \mu \mathrm{M}$ (Table 1). The enantiomers containing $\mathbf{L}^{\mathbf{1 a}}$ were generally the most potent, and while a direct comparison with related helicates ${ }^{33,34}$ is not easy to make, reference to the cisplatin control experiments indicates that the activities here are at least comparable with the more recently reported arginine derivatives of Hannon. ${ }^{40}$ The most striking result however is that flexicates based on $\mathbf{L}^{\mathbf{1 a}}$ exhibit potent cytotoxic effects on the cisplatin-resistant ovarian tumour cell line A2780cis. The effect is marked; there is an approximate 5 -fold difference between the $\mathrm{IC}_{50}$ values for these flexicates and cisplatin towards A2780cis. Furthermore A2780cis is more sensitive to these $\mathbf{L}^{\mathbf{1 a}}$ flexicates than is the parental line A2780.

The flexicates based on $\mathbf{L}^{\mathbf{2 a / 2} \mathbf{b}}$ are generally less cytotoxic but the differences in sensitivity between cell lines (i.e. selectivity) is marked. In particular A2780cis is resistant to these compounds, with $\mathrm{IC}_{50}$ values 2-6 times higher than those for the parent cell line. At the same time, some of the differences in $\mathrm{IC}_{50}$ between enantiomers are very significant with the $\Lambda$-[Fe $\left.\mathbf{F}_{2} \mathbf{L}_{3}^{2 \mathbf{a}}\right] \mathrm{Cl}_{4}$ isomer being more potent. Again, this contrasts with the $\mathbf{L}^{\mathbf{1 a}}$ complex enantiomers where only marginal differences were observed.

\begin{tabular}{|c|c|c|c|c|}
\hline \multirow[b]{2}{*}{ Complex } & \multicolumn{4}{|c|}{$\mathrm{IC}_{50} / \mu \mathrm{M}$ (esd) } \\
\hline & MCF7 & A2780 & A2780cis & HCT116 p53 \\
\hline Cisplatin & $1.33(0.23)$ & $0.93(0.04)$ & $10.46(0.15)$ & $3.51(1.50)$ \\
\hline$\Lambda-\left[\mathrm{Fe}_{2} \mathbf{L}_{3}{ }^{1 \mathrm{a}}\right] \mathrm{Cl}_{4}$ & $3.67(0.14)$ & $4.80(0.15)$ & $2.18(0.07)$ & $1.66(1.05)$ \\
\hline$\Delta-\left[\mathrm{Fe}_{2} \mathbf{L}_{3}{ }^{1 \mathrm{a}}\right] \mathrm{Cl}_{4}$ & $2.95(0.77)$ & $3.75(0.10)$ & $2.39(0.12)$ & $0.61(0.31)$ \\
\hline$\Lambda \cdot\left[\mathrm{Fe}_{2} \mathbf{L}_{3}^{2 \mathbf{a}}\right] \mathrm{Cl}_{4}$ & $5.50(0.52)$ & $3.29(0.09)$ & $7.34(0.32)$ & $0.62(0.08)$ \\
\hline$\Delta-\left[\mathrm{Fe}_{2} \mathbf{L}_{3}^{2 \mathrm{a}}\right] \mathrm{Cl}_{4}$ & $10.16(0.18)$ & $3.48(0.04)$ & $14.39(0.39)$ & $0.87(0.13)$ \\
\hline$\Lambda-\left[\mathrm{Fe}_{2} \mathbf{L}_{3}^{\mathbf{2 b}}\right] \mathrm{Cl}_{4}$ & $6.08(0.21)$ & $4.29(0.08)$ & $12.72(0.03)$ & $0.64(0.15)$ \\
\hline$\Delta-\left[\mathrm{Fe}_{2} \mathbf{L}_{3}^{2 \mathbf{b}}\right] \mathrm{Cl}_{4}$ & $8.26(0.16)$ & $3.10(0.10)$ & $18.20(0.15)$ & $0.61(0.07)$ \\
\hline
\end{tabular}

Table 1 Anticancer activities of the flexicates 
The HCT116 p53 ${ }^{+/+}$cell line is sensitive to all the flexicates and $\mathrm{IC}_{50}$ values in the $\mathrm{nM}$ range are observed, significantly lower than the cisplatin control.

Across the panel there are large differences in sensitivity to individual compounds e.g. a factor of $c a 30$ in sensitivity between the highest and lowest $\mathrm{IC}_{50}$ observations for $\Delta-\left[\mathrm{Fe}_{2} \mathbf{L}_{3}^{2 \mathbf{b}}\right] \mathrm{Cl}_{4}$.

Given the range of $\mathrm{IC}_{50}$ values in Table 1 and the ready availability and stability in water of enantiomers of the test compounds we have been able to address in more detail the relationship between the binding of various DNA motifs and cytotoxicity.

\section{Atomic force microscopy}

The influence of the flexicates on the tertiary structure of single DNA molecules was studied by direct visualisation of linearized plasmid pSP73 (2464 bp) mixed with increasing concentrations of the flexicates using atomic force microscopy (AFM) tapping mode in air. Samples for imaging were prepared by adsorption of the flexicates onto freshly cleaved mica in the presence of $5 \mathrm{mM} \mathrm{Mg}$ (II). The non-modified linearized plasmid molecules appeared as relaxed and well-separated strands; crossing strands were rarely observed [see ESI, Fig. S1(a and b) †]. The addition of $\left[\mathrm{Fe}_{2} \mathbf{L}_{3}^{\mathbf{1 a}}\right] \mathrm{Cl}_{4}$ and $\left[\mathrm{Fe}_{2} \mathbf{L}_{3}{ }_{3}{ }_{3} \mathrm{Cl}_{4}\right.$ flexicates affected the conformation of linear plasmid DNA yielding typical images as shown in Fig. 3.

For $\left[\mathrm{Fe}_{2} \mathbf{L}_{3}^{1 \mathbf{a}}\right] \mathrm{Cl}_{4}$, an increase in formation of loops and close strand contacts was seen for both enantiomers at lower DNA base : flexicate ratios up to $\sim 5: 1$ (shown for $\Lambda$-enantiomer in Fig. 3(A)). On increasing the concentration of flexicates (Fig. 3(B and $\mathrm{C}$ )) intramolecular coiling and intermolecular aggregation of DNA molecules was more pronounced. A level of cooperativity in the coiling process was apparent, since clusters and fully coiled DNA strands were observed in the presence of uncoiled DNA molecules. The extent of coiling and aggregation was slightly higher for the $\Lambda$ enantiomer than the $\Delta$ enantiomer. The effects of the $\left[\mathrm{Fe}_{2} \mathbf{L}_{3}^{\mathbf{1 a}}\right] \mathrm{Cl}_{4}$ flexicates on DNA coiling differ from that reported for the $\left[\mathrm{Fe}_{2}(\mathbf{I})_{3}\right] \mathrm{Cl}_{4}$ helicate ${ }^{32}$ which induced almost exclusively intramolecular coiling of individual DNA molecules and did not exhibit a tendency to condense DNA into intermolecular clusters [see ESI, Fig. S1(c)†].

Typical AFM images of linear DNA mixed with $\left[\mathrm{Fe}_{2} \mathbf{L}_{3}^{2 \mathbf{a}}\right] \mathrm{Cl}_{4}$ are shown in Fig. 3(D-F) and indicate different behaviour from $\left[\mathrm{Fe}_{2} \mathbf{L}_{3}^{\mathbf{1 a}}\right] \mathrm{Cl}_{4}$. No intramolecular coiling was observed even at high loadings of $\left[\mathrm{Fe}_{2} \mathbf{L}^{2 \mathbf{a}}{ }_{3}\right] \mathrm{Cl}_{4}$ (Fig. 3(F)). Thick-stranded features made by tight coiling of two individual DNA strands and some intermolecular aggregates were predominantly seen (Fig. 3(E and F)). To observe a similar level of DNA condensation as seen with the $\left[\mathrm{Fe}_{2} \mathbf{L}_{3}^{\mathbf{1 a}}\right] \mathrm{Cl}_{4}$ flexicates, the concentration of $\left[\mathrm{Fe}_{2} \mathbf{L}_{3}^{2 \mathbf{a}}\right] \mathrm{Cl}_{4}$ was required to be approximately 10-20-fold higher. No difference between enantiomers was noticed. These observations are entirely consistent with the $\left[\mathrm{Fe}_{2} \mathbf{L}_{3}^{\mathbf{2 a}}\right] \mathrm{Cl}_{4}$ flexicates only showing weak electrostatic binding to DNA.

\section{DNA binding studies using spectroscopic methods}

Circular dichroism titration experiments were used to investigate the binding of the water soluble $\left[\mathrm{Fe}_{2} \mathrm{~L}_{3}\right] \mathrm{Cl}_{4}$ flexicate
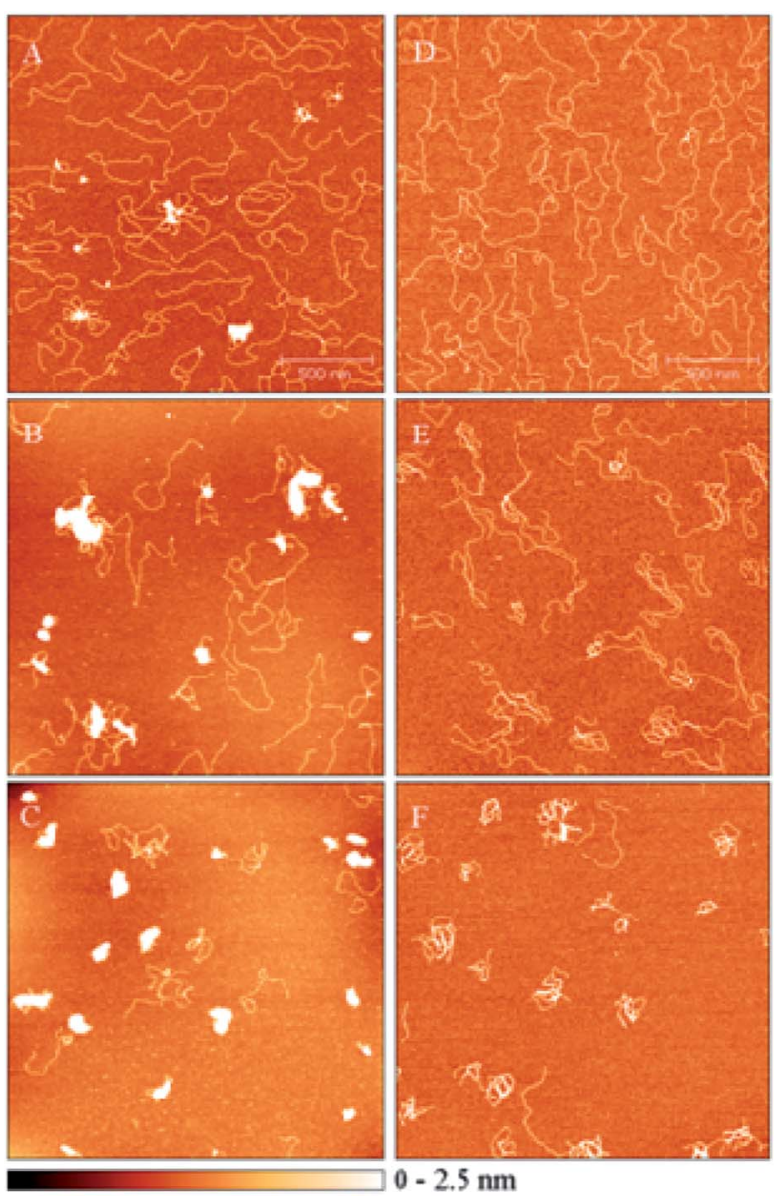

Fig. 3 AFM images of linear plasmid pSP73 (2464 bp) mixed with flexicates at various DNA base : flexicate ratios. (A-C) DNA with $\Lambda_{\mathrm{Fe},} S_{\mathrm{C}}-\left[\mathrm{Fe}_{2} \mathbf{L}^{\mathbf{1 a}}{ }_{3}\right] \mathrm{Cl}_{4}$ at $5: 1$, $3: 1$ and $2: 1$ ratios, respectively. (D-F) DNA with $\Lambda_{\mathrm{Fe}_{1}} R_{\mathrm{C}^{-}}\left[\mathrm{Fe}_{2} \mathbf{L}^{\left.2 \mathbf{a}_{3}\right] C l_{4}}\right.$ at $1: 2,1: 4$ and $1: 6$ ratios, respectively.

enantiomers to calf-thymus DNA (ct-DNA) as shown in Fig. 4 and in ESI. $\uparrow$ Changes to peaks below $300 \mathrm{~nm}$ are predominantly due to the intrinsic ct-DNA CD signals that occur in this region. In the MLCT region, i.e. that of the intense bisignate curves

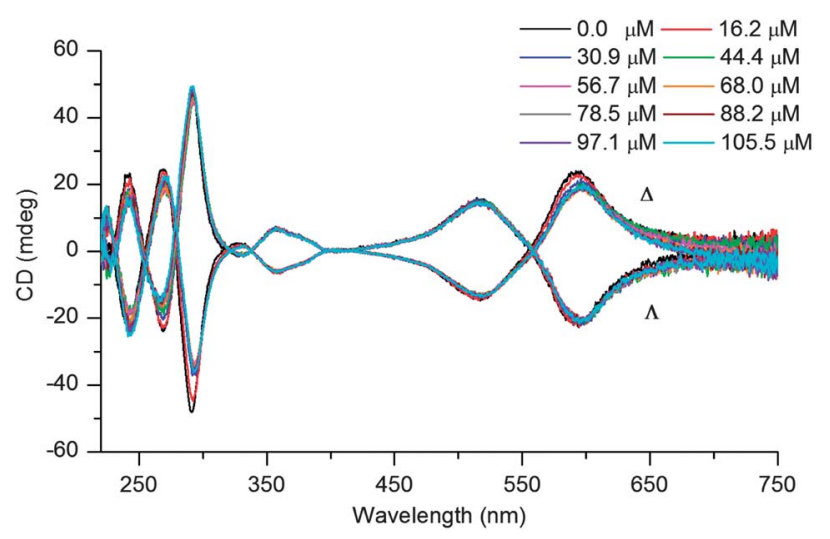

Fig. $4 \mathrm{CD}$ titration series for $\Delta_{\mathrm{Fe}} / \Lambda_{\mathrm{Fe}}-\left[\mathrm{Fe}_{2} \mathrm{~L}^{\mathbf{1 a}}{ }_{3}\right] \mathrm{Cl}_{4}$ at constant flexicate concentrations $(15 \mu \mathrm{M})$ and increasing ct-DNA concentrations (indicated in legend). TRIZMA® base buffer (1 mM, pH 7.2). Path length $1.0 \mathrm{~cm}$. 


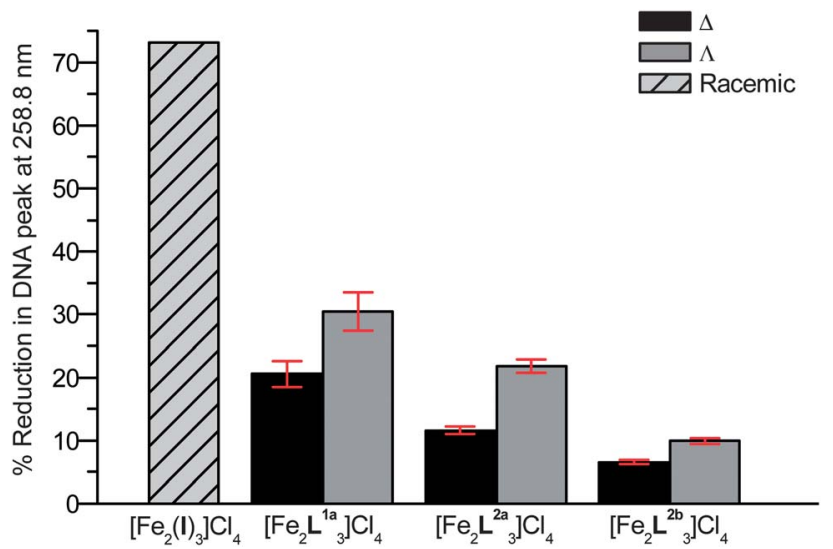

Fig. 5 Comparison of the reduction in the linear dichroism absorption of the ctDNA $260 \mathrm{~nm}$ peak in the presence of various complexes. DNA base : complex ratio $7: 1$ throughout. Values for $\Delta_{\mathrm{Fe}} / \Lambda_{\mathrm{Fe}}-\left[\mathrm{Fe}_{2} \mathbf{L}^{\left.1{ }^{1}{ }_{3}\right] C_{4}}\right.$ flexicates are calculated using film LD and UV-Vis absorbance data. Data from Hannon and co-workers taken from previously reported work. ${ }^{32,47}$

between 450 and $650 \mathrm{~nm}$, subtle changes in the intensity and wavelength are consistent with distortion of the complex in the region of the $\mathrm{Fe}$ (pyridine/imine) ${ }_{3}$ chromophore on binding to the DNA. The $\Delta_{\mathrm{Fe}}, R_{\mathrm{C}}-\left[\mathrm{Fe}_{2} \mathbf{L}_{3}^{1 \mathbf{a}}\right] \mathrm{Cl}_{4}$ flexicate shows the largest change of the tested complexes. The changes in the CD of the corresponding $\Lambda$ isomer of $\mathbf{L}^{\mathbf{1 a}}$ (Fig. 4 ) as well as of the flexicates based on $\mathbf{L}^{2 \mathbf{a}}$ and $\mathbf{L}^{\mathbf{2 b}}$ (see ESI, Fig. S2 and S3 $\dagger$ ) are much smaller and therefore suggest smaller distortions to the geometries of the complexes on binding to DNA. Perturbations of chargetransfer absorptions were also observed in ct-DNA/[ $\left[\mathrm{Fe}_{2}(\mathbf{I})_{3}\right]^{4+}$ solutions. $^{46}$

The extent to which these interactions cause disruption in the DNA structure in solution may be estimated from the reduction in the intensity of the DNA linear dichroism (LD) absorption at ca $260 \mathrm{~nm}$. Suitable linear dichroism (LD) spectra (Fig. S4-S9) and details of calculation of the peak intensity are given in ESI. $\uparrow$ The data are summarised in Fig. 5. This reduction in intensity almost certainly comes from bending or coiling, as we have seen in the solid state by AFM, that reduces alignment of the DNA with the laminar flow in the cell. It is rather less likely to result from an increase in the flexibility of the DNA. The percentage reduction in the DNA peak follows the trend $\mathbf{L}^{\mathbf{1 a}}>$ $\mathbf{L}^{2 \mathbf{a}}>\mathbf{L}^{\mathbf{2 b}}$. The $\Lambda_{\mathrm{Fe}}$ compounds cause more disruption to the DNA structure, indicating stronger preferences for binding with the $\Lambda_{\mathrm{Fe}}$ enantiomer in each case. In comparison to the iron(II) flexicates reported here, $\left[\mathrm{Fe}_{2}(\mathrm{I})_{3}\right]^{4+}$ causes a higher degree of disruption to the DNA structure at the same DNA base : complex ratio ${ }^{32,47}$ and this correlates well with AFM data.

\section{DNase I footprinting}

In order to obtain information on sequence-specificity in the binding events that appear to lead to the tertiary structure changes described above, footprinting methodology was used. Deoxyribonuclease I (DNase I) is the most commonly used nuclease for these experiments and the reaction conditions used were such that, on average, each DNA strand was cut once giving a mixture of different fragments. A compound bound to DNA protects the DNA from cleavage at their binding sites.

Each flexicate was mixed with the 158 bp HindIII/NdeI restriction fragment of pSP73 followed by partial cleavage by DNase I. The autoradiograms of the DNA cleavage inhibition patterns are shown in Fig. 6. Comparing the patterns observed in the presence and absence of the flexicates shows some evidence of footprints in the gel particularly for the $\Lambda_{\mathrm{Fe}}, S_{\mathrm{C}^{-}}$ $\left[\mathrm{Fe}_{2} \mathbf{L}_{3}^{\mathbf{1 a}}\right] \mathrm{Cl}_{4}$ flexicate around positions 50 and 70 (Fig. 6(a), lane 2 and Fig. 6(b), lanes 2,3) indicating specific sequences in DNA are recognised. There are only minor differences between the autoradiograms for the flexicates at 20:1 and 10:1 (DNA base : flexicate) ratios (Fig. 6(b)). a)

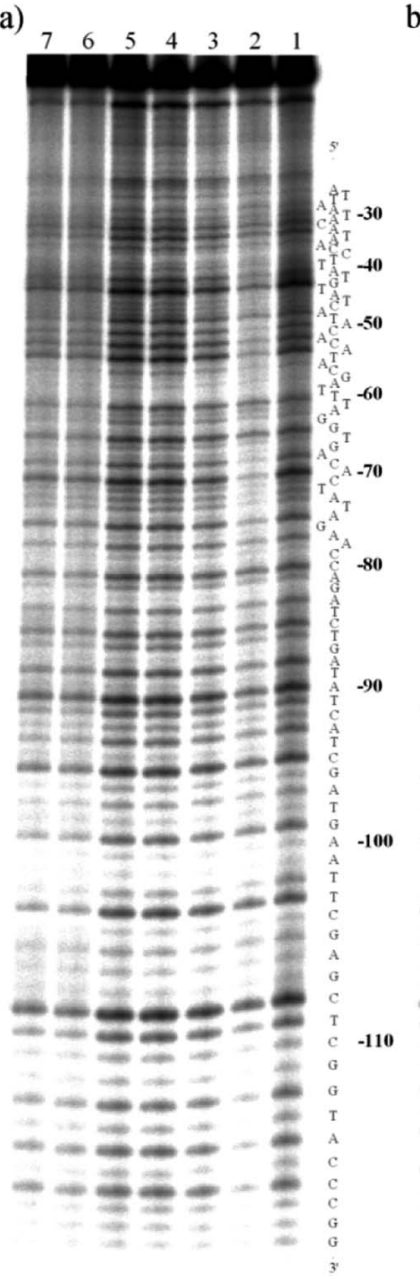

b) \begin{tabular}{llllllll}
5 & 4 & 3 & 2 & 1 & \multirow{6}{5}{} & $\mathrm{G}$
\end{tabular}

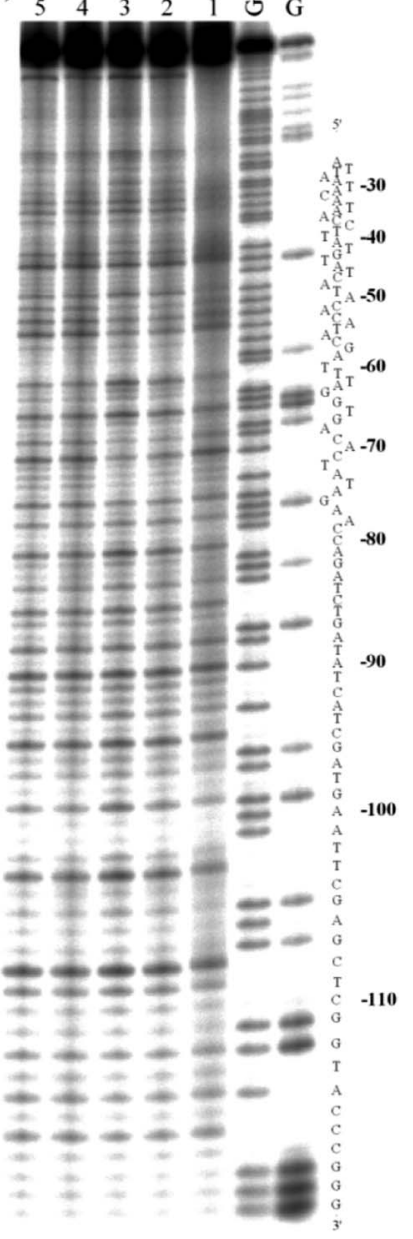

Fig. 6 Autoradiogram of DNase I footprint of $3^{\prime}$ end labeled top strand of the $158 \mathrm{bp} \mathrm{HindIII/Ndel} \mathrm{restriction} \mathrm{fragment} \mathrm{of} \mathrm{the} \mathrm{plasmid} \mathrm{pSP73} \mathrm{in} \mathrm{the} \mathrm{presence} \mathrm{of}$ the flexicates. The nucleotide sequence of the fragment is shown on the right side of the gel and numbers refer to the sequence shown in the corresponding differential cleavage plots in Fig. 8. For (a) lane 1: DNA in the absence of flexicates, lanes 2-7: DNA mixed with $\Lambda_{\mathrm{Fe},}, S_{C^{-}}\left[\mathrm{Fe}_{2} \mathbf{L}^{1 \mathbf{a}_{3}}\right] \mathrm{Cl}_{4}, \Delta_{\mathrm{Fe},}, R_{\mathrm{C}^{-}}\left[\mathrm{Fe}_{2} \mathbf{L}^{1 \mathbf{a}_{3}}\right] \mathrm{Cl}_{4}, \Lambda_{\mathrm{Fe},}, R_{\mathrm{C}^{-}}$ $\left[\mathrm{Fe}_{2} \mathbf{L}^{\mathbf{2 a}}{ }_{3}\right] \mathrm{Cl}_{4}, \Delta_{\mathrm{Fe}}, \mathrm{S}_{\mathrm{C}}\left[\mathrm{Fe}_{2} \mathbf{L}^{\mathbf{2 a}}{ }_{3}\right] \mathrm{Cl}_{4}, \Lambda_{\mathrm{Fe}}, \mathrm{S}_{\mathrm{C}}\left[\mathrm{Fe}_{2} \mathbf{L}^{\mathbf{2 b}}{ }_{3}\right] \mathrm{Cl}_{4}, \Delta_{\mathrm{Fe}}, R_{\mathrm{C}}\left[\left[\mathrm{Fe}_{2} \mathbf{L}^{\mathbf{2 b}}{ }_{3}\right] \mathrm{Cl}_{4}\right.$ respectively. All at $10: 1$ (DNA base : flexicate) ratios. For (b) lane 1: DNA in the absence of flexicates, lanes 2 and 3: DNA mixed with $\Lambda_{\mathrm{Fe}} S_{\mathrm{C}}-\left[\mathrm{Fe}_{2} \mathbf{L}^{1{ }^{1}}{ }_{3}\right] \mathrm{Cl}_{4}$ at $20: 1$ and 10: 1 (DNA base : flexicate) ratios respectively, lanes 4 and 5: DNA mixed with $\Delta_{\mathrm{Fe},} R_{\mathrm{C}}\left[\mathrm{Fe}_{2} \mathbf{L}^{\mathbf{1 a}}{ }_{3}\right] \mathrm{Cl} \mathrm{C}_{4}$ at $20: 1$ and $10: 1$ ratios respectively, lanes $\mathrm{G}+\mathrm{A}$ and $\mathrm{G}$ correspond to Maxam-Gilbert $\mathrm{G}+\mathrm{A}$ and $\mathrm{G}$ ladders. 
Further information on the binding specificity of the $\left[\mathrm{Fe}_{2} \mathbf{L}_{3}^{\mathbf{1}}{ }_{3}\right] \mathrm{Cl}_{4}$ enantiomers was obtained from the intensities of the bands from the gel lanes in Fig. 6. For bands containing DNA mixed with the $\left[\mathrm{Fe}_{2} \mathbf{L}^{\mathbf{1 a}}{ }_{3}\right] \mathrm{Cl}_{4}$ enantiomers at $10: 1$ (DNA base : flexicate) ratios were measured by densitometry and the resulting differential cleavage plots are shown in Fig. 7. Negative values indicate inhibition of DNase I cleavage at that section whereas positive values indicate enhancement. It can be seen that $\Delta_{\mathrm{Fe}}, R_{\mathrm{C}}\left[\mathrm{Fe}_{2} \mathbf{L}^{1 \mathbf{a}}{ }_{3}\right] \mathrm{Cl}_{4}$ does not display significant patterns of protection and enhancement. Conversely, the differential cleavage plot for $\Lambda_{\mathrm{Fe}}, S_{\mathrm{C}}-\left[\mathrm{Fe}_{2} \mathbf{L}^{1 \mathbf{a}}{ }_{3}\right] \mathrm{Cl}_{4}$ contains two major regions where the flexicate has protected the DNA from DNase I cleavage. These sites are centred around positions 52 and 70 and extend over approximately 5-6 bp. Applying a shift of 2-3 bp in the $3^{\prime}$ direction is necessary to correct for the fact that DNase I binds across the minor groove. ${ }^{48,49}$ From this assumption, the two preferential binding sites of $\Lambda_{\mathrm{Fe}}, S_{\mathrm{C}^{-}}$ $\left[\mathrm{Fe}_{2} \mathbf{L}_{3}{ }_{3}{ }_{3}\right] \mathrm{Cl}_{4}$ can be deduced as 5'-CACATA and 5'-CACTAT starting at positions 51 and 69, respectively. Hence there appear to be fewer preferential binding sites than has been observed $^{31,50}$ for $\left[\mathrm{Fe}_{2}(\mathbf{I})_{3}\right]^{4+}$ and $\left[\mathrm{Ru}_{2}(\mathbf{I})_{3}\right]^{4+}$.

\section{Supramolecular interactions of flexicates with oligonucleotide motifs}

In this section we investigate the possibility of flexicate interactions with other potential drug target DNA structures relevant to DNA replication and recombination.

\section{Three-way junctions}

Three-way junctions (3WJs) consist of three double strands converging at one point (Fig. 8). ${ }^{51}$ Typically found in both DNA (e.g. replication forks) ${ }^{52}$ and $\mathrm{RNA}^{53}$ they are potential drug targets. Fig. 8 (a) shows a Y-shaped $3 \mathrm{WJ}\left(T_{\mathrm{m}}=35.0^{\circ} \mathrm{C}\right)$ of the type shown to bind one particular helicate molecule in the central cavity. ${ }^{54}$ T-shaped $3 \mathrm{WJs}$, which do not in their relaxed state have such a cavity are found where unpaired bases appear in the junction region; ${ }^{51}$ the systems of Fig. $8(\mathrm{~b}$ and c) have two unpaired adenosines (3WJ-AA) and two unpaired thymidines (3WJ-TT) and higher melting temperatures of $41.4{ }^{\circ} \mathrm{C}$ and
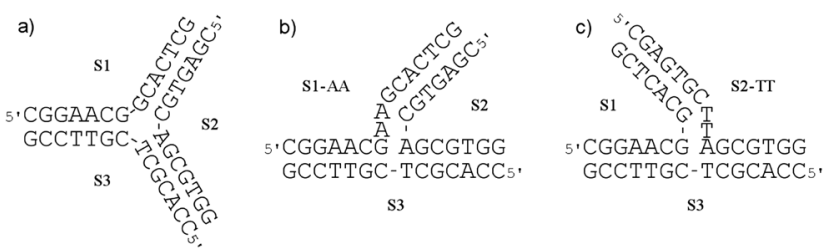

Fig. 8 The sequences of the oligonucleotides used to form (a) Y-shaped 3WJ, and T-shaped 3WJs containing two unpaired (b) adenosines 3WJ-AA or (c) thymidines 3WJ-TT at the branch point of the junction.

$38.5^{\circ} \mathrm{C}$ respectively. As shown in Table 2, addition of flexicates to solutions of all of these oligonucleotide assemblies increases the melting temperatures $\left(T_{\mathrm{m}}\right)$ i.e. increases thermal stability.

The $\mathbf{L}^{\mathbf{1 a}}$ flexicates are consistently more efficient at stabilising the $3 \mathrm{WJ}$ s than are the $\mathrm{L}^{2}$ flexicates. In all cases, doubling the ratio from $1: 1$ to $2: 1$ (flexicate : $3 \mathrm{WJ}$ ) had almost no further effect on the stability suggesting all the $3 \mathrm{WJ}$ contain just one major binding site.

Gel electrophoresis was used to gain more information about the stabilisation effect that the flexicates bring to DNA $3 \mathrm{WJs} .{ }^{55}$ The three 14 base single strand oligonucleotides used in the Y-shaped 3WJ of Fig. 8(a) provide the minimum length required for the assembly to persist during electrophoresis at low temperatures $\left(5{ }^{\circ} \mathrm{C}\right)$ in the presence of magnesium(II) ions. ${ }^{56}$

Table 2 Effect of flexicates on thermal stability of $Y$ - and T-shaped 3 WJs at $1: 1$ and $2: 1$ (flexicate : $3 \mathrm{WJ}$ ) ratios

\begin{tabular}{|c|c|c|c|c|c|c|}
\hline \multirow[b]{2}{*}{ Complex } & \multicolumn{2}{|c|}{$\begin{array}{l}\text { Y-shaped } \\
3 \mathrm{WJ} \Delta T_{\mathrm{m}}\left({ }^{\circ} \mathrm{C}\right) \\
\end{array}$} & \multicolumn{2}{|c|}{$\begin{array}{l}\text { T-shaped } \\
\text { 3WJ-AA } \Delta T_{\mathrm{m}} \\
\left({ }^{\circ} \mathrm{C}\right) \\
\end{array}$} & \multicolumn{2}{|c|}{$\begin{array}{l}\text { T-shaped } \\
3 \mathrm{WJ}-\mathrm{TT} \Delta T_{\mathrm{m}} \\
\left({ }^{\circ} \mathrm{C}\right) \\
\end{array}$} \\
\hline & $1: 1$ & $2: 1$ & $1: 1$ & $2: 1$ & $1: 1$ & $2: 1$ \\
\hline$\Lambda-\left[\mathrm{Fe}_{2} \mathbf{L}_{3}^{\mathbf{1 a}}\right] \mathrm{Cl}_{4}$ & 20.1 & 20.3 & 8.3 & 9.4 & 9.6 & 10.7 \\
\hline$\Delta-\left[\mathrm{Fe}_{2} \mathbf{L}^{1 \mathbf{a}}\right] \mathrm{Cl}_{4}$ & 18.2 & 18.5 & 7.0 & 8.1 & 9.6 & 10.7 \\
\hline$\Lambda-\left[\mathrm{Fe}_{2} \mathbf{L}_{3}^{2 \mathbf{a}}\right] \mathrm{Cl}_{4}$ & 9.0 & 10.4 & 0.2 & 0.4 & 2.8 & 3.6 \\
\hline$\Delta-\left[\mathrm{Fe}_{2} \mathbf{L}^{2 \mathbf{a}}{ }_{3}\right]_{3} \mathrm{Cl}_{4}$ & 13.1 & 12.6 & 1.7 & 2.5 & 5.4 & 6.2 \\
\hline$\Lambda-\left[\mathrm{Fe}_{2} \mathbf{L}^{2 \mathbf{b}}{ }_{3}\right] \mathrm{Cl}_{4}$ & 7.1 & 8.9 & 0.5 & 0.8 & 2.6 & 3.5 \\
\hline$\Delta-\left[\mathrm{Fe}_{2} \mathbf{L}^{2 \mathbf{b}}{ }_{3}\right] \mathrm{Cl}_{4}$ & 11.0 & 11.8 & 1.6 & 2.4 & 5.1 & 6.2 \\
\hline
\end{tabular}

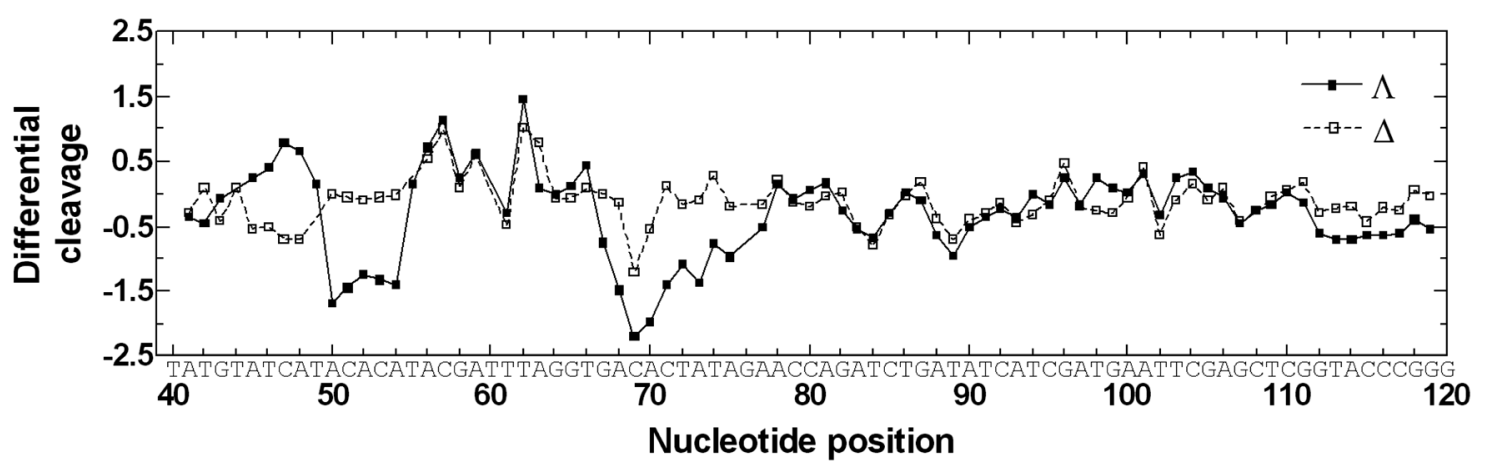

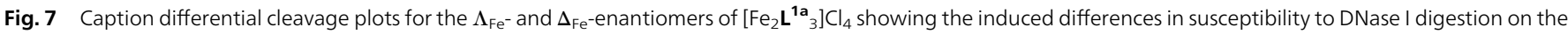

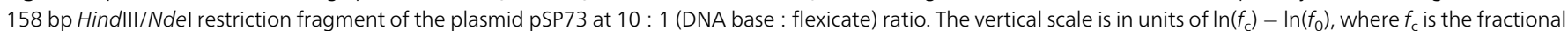

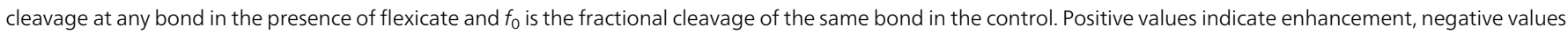
indicate inhibition. 
Without $\mathrm{Mg}^{2+}$ ions present, these $3 \mathrm{WJ}$ s split into single strands [Fig. 9(a) lane C]. Fig. 9(a) shows that both $\left[\mathrm{Fe}_{2} \mathbf{L}_{3}^{1 \mathbf{a}}\right]^{4+}$ enantiomers (lanes 1-6) are able to stabilise the Y-shaped 3WJ during electrophoresis in the absence of $\mathrm{Mg}^{2+}$ at room temperature. The L ${ }^{2}$ flexicates, $\Delta_{\mathrm{Fe}} / \Lambda_{\mathrm{Fe}}-\left[\mathrm{Fe}_{2} \mathbf{L}_{3}{ }_{3}\right] \mathrm{Cl}_{4}$ (lanes 7,8$)$ and $\Delta_{\mathrm{Fe}} / \Lambda_{\mathrm{Fe}^{-}}$ $\left[\mathrm{Fe}_{2} \mathbf{L}_{3}^{2 \mathbf{b}}\right] \mathrm{Cl}_{4}$ (lanes 9, 10), had no or very little effect on the stability of this $3 \mathrm{WJ}$ under these conditions. Consistent with the melting experiments above, a plot of the percentage of $3 \mathrm{WJS}$ remaining after electrophoresis as a function of flexicate concentration [Fig. 9(b)] clearly shows that for $\left[\mathrm{Fe}_{2} \mathbf{L}_{3}^{\mathbf{1 a}}\right] \mathrm{Cl}_{4}$, the $\Lambda_{\mathrm{Fe}}$ enantiomer stabilises the Y-shaped $3 \mathrm{WJ}$ during electrophoresis to a greater extent compared with the $\Delta_{\mathrm{Fe}}$ enantiomer (Fig. 10).

The related gel electrophoresis experiments on the T-shaped 3WJs of Fig. 8(b and c)] show an extraordinary difference in the behaviour of enantiomers $\Delta_{\mathrm{Fe}} / \Lambda_{\mathrm{Fe}}-\left[\mathrm{Fe}_{2} \mathbf{L}^{\mathbf{1 a}}{ }_{3}\right] \mathrm{Cl}_{4}$; with both $3 \mathrm{WJ}$ AA and $3 \mathrm{WJ}-\mathrm{TT}$, stabilisation was only observed with the $\Lambda_{\mathrm{Fe}}$ enantiomer (lanes 1-3 and 7-9).

The mechanisms of binding to Y- and T-shaped 3WJ must thus differ. With the Y-shaped $3 \mathrm{WJ}$, it is likely that the flexicates bind to the central hollow cavity at the branch point of the junction $;^{54}$ notably the $\Delta T_{\mathrm{m}}$ are consistently higher for these "preorganised" systems. In contrast for the T-shaped 3WJs we propose the structure of the junction may be being changed on binding to accommodate the flexicate; something that may explain the enhanced enantioselectivity.

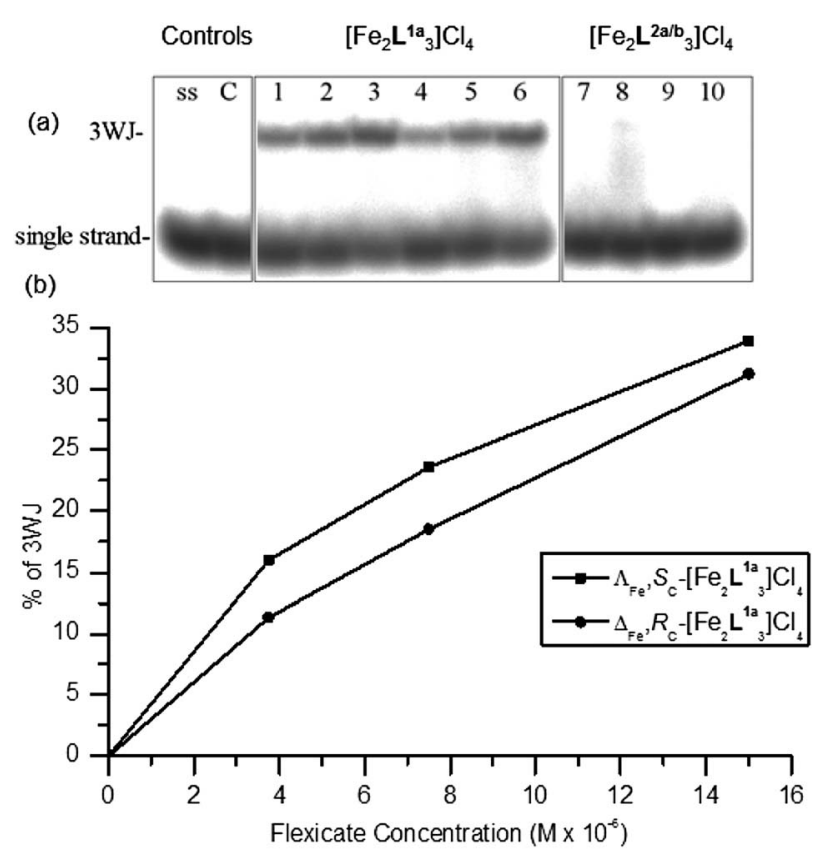

Fig. 9 (a) Autoradiogram of the gel run at room temperature. Lane ss: control containing a single strand. Lane C: control containing all three strands $\mathrm{S} 1, \mathrm{~S} 2$ and S3. Lane 1-3: S1, S2 and S3 mixed with $\Lambda_{\mathrm{Fe},} S_{\mathrm{C}^{-}}\left[\mathrm{Fe}_{2} \mathbf{L}^{1 \mathbf{a}_{3}}\right] \mathrm{Cl}_{4}$ at $0.5: 1,1: 1$ and $2: 1$ (flexicate: $3 \mathrm{WJ}$ ) ratios, respectively. Lanes $4-6: \mathrm{S} 1, \mathrm{~S} 2$ and $\mathrm{S} 3$ mixed with

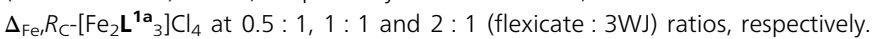
Lanes 7-10: S1, S2 and S3 mixed with $\Lambda_{\mathrm{Fe},} R_{\mathrm{C}}-\left[\mathrm{Fe}_{2} \mathbf{L}_{3} \mathbf{2 a}_{3}\right] \mathrm{Cl}_{4}(7), \Delta_{\mathrm{Fe},} \mathrm{S}_{\mathrm{C}}\left[\mathrm{Fe}_{2} \mathbf{L}^{\mathbf{2 a}}\right] \mathrm{Cl}_{4}$ (8), $\Lambda_{\mathrm{Fe},} S_{\mathrm{C}^{-}}\left[\mathrm{Fe}_{2} \mathbf{L}^{\mathbf{2} \mathbf{b}_{3}}\right] \mathrm{Cl}_{4}$ (9) and $\Delta_{\mathrm{Fe}}, R_{\mathrm{C}}-\left[\mathrm{Fe}_{2} \mathbf{L}^{\mathbf{2 b}}{ }_{3}\right] \mathrm{Cl}_{4}(10)$ at $1: 1$ (flexicate : 3WJ) ratio. (b) Plot of the \% of $3 \mathrm{WJ}$ s remaining after electrophoresis as a function of flexicate concentration.

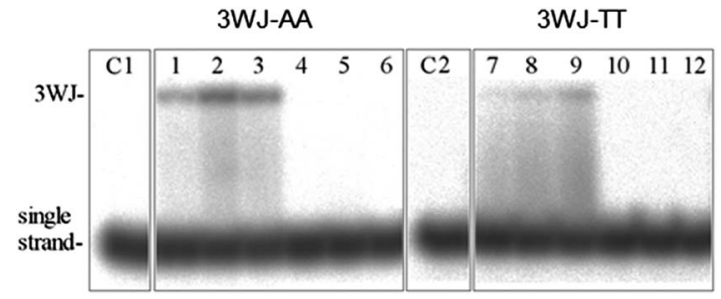

Fig. 10 Autoradiograms of the gels run at room temperature. Lane C1: control containing the three strands, S1-AA, S2 and S3. Lanes 1-3: S1-AA, S2 and S3 mixed with $\Lambda_{\mathrm{Fe}}, S_{\mathrm{C}^{-}}\left[\mathrm{Fe}_{2} \mathbf{L}^{\mathbf{1 a}_{3}}\right] \mathrm{Cl}_{4}$ at $0.5: 1,1: 1$ and $2: 1$ (flexicate : 3WJ) ratios, respectively. Lanes 4-6: S1-AA, S2 and S3 mixed with $\Delta_{\mathrm{Fe},}, R_{\mathrm{C}^{-}}\left[\mathrm{Fe}_{2} \mathbf{L}^{\mathbf{1 a}_{3}}\right] \mathrm{Cl} \mathrm{l}_{4}$ at $0.5: 1$, $1: 1$ and $2: 1$ (flexicate : $3 \mathrm{WJ}$ ) ratios, respectively. Lane $\mathrm{C2}$ : control containing the three strands, S1-TT, S2 and S3. Lanes 7-9: S1-TT, S2 and S3 mixed with $\Lambda_{\mathrm{Fe}} \mathrm{S}_{\mathrm{C}^{-}}$ $\left[\mathrm{Fe}_{2} \mathbf{L}^{1 \mathbf{a}_{3}}\right] \mathrm{Cl}_{4}$ at $0.5: 1,1: 1$ and $2: 1$ (flexicate : 3WJ) ratios, respectively. Lanes 4-6: S1-TT, S2 and S3 mixed with $\Delta_{\mathrm{Fe}_{2}} R_{\mathrm{C}-}\left[\mathrm{Fe}_{2} \mathbf{L}^{{ }^{1 \mathbf{a}}}{ }_{3}\right] \mathrm{Cl}_{4}$ at $0.5: 1,1: 1$ and $2: 1$ (flexicate : $3 \mathrm{WJ}$ ) ratios, respectively.

We note that while only $\Lambda$ isomer of $\left[\mathrm{Fe}_{2} \mathbf{L}_{3}^{\mathbf{1 a}}\right] \mathrm{Cl}_{4}$ stabilizes T-shaped 3WJ-TT during gel electrophoresis, both $\Lambda$ and $\Delta$ compounds increase the melting temperatures equally. A plausible explanation might be while the gel electrophoresis in the absence of $\mathrm{Mg}^{2+}$ was carried out at room temperature $\left(22^{\circ} \mathrm{C}\right)$ and observes the proportion of $3 \mathrm{WJ}$ s remaining after electrophoresis, the melting temperatures $\left(\sim 40{ }^{\circ} \mathrm{C}\right)$ rather reflect the properties of the $3 \mathrm{WJ}$ s at the elevated temperatures when $3 \mathrm{WJs}$ start to melt. Thus, melting temperatures may not reflect relatively small differences in the capability of the two isomers to stabilize T-shaped 3WJs-TT whereas the gel electrophoresis apparently can.

\section{Four-way junctions}

Four-way junctions (4WJs), e.g. the Holliday junction, ${ }^{57}$ consist of four double strands converging at one point and are also potential DNA drug targets. ${ }^{58}$ The thermal stability of the $4 \mathrm{WJ}$ shown in Fig. $11\left(T_{\mathrm{m}}=42.4{ }^{\circ} \mathrm{C}\right)$ in the presence of the flexicates was investigated. The $\mathrm{L}^{2}$ systems $\left(\Delta_{\mathrm{Fe}} / \Lambda_{\mathrm{Fe}}\left[\mathrm{Fe}_{2} \mathbf{L}_{3}{ }_{3}{ }_{3}\right] \mathrm{Cl}_{4}\right.$ and $\Delta_{\mathrm{Fe}} /$ $\left.\Lambda_{\mathrm{Fe}}\left[\mathrm{Fe}_{2} \mathbf{L}_{3}^{2 \mathbf{b}}\right] \mathrm{Cl}_{4}\right)$ had small or even a negative effect on the stability of this $4 \mathrm{WJ}$ (Table 3 ). The melting temperature was, however, found to increase in the presence of both enantiomers of the $\left[\mathrm{Fe}_{2} \mathbf{L}_{3}^{\mathbf{1 a}}\right] \mathrm{Cl}_{4}$ flexicates with the $\Lambda_{\mathrm{Fe}}$ enantiomer providing some additional stability in comparison to the $\Delta_{\mathrm{Fe}}$ enantiomer. Additionally it was found that the increase in melting temperature of this $4 \mathrm{WJ}$ as the concentration of the $\mathbf{L}^{\mathbf{1 a}}$ flexicates increases above the stoichiometric ratio suggests that, unlike the $3 \mathrm{WJ}$, the $4 \mathrm{WJ}$ contains more than one binding site for these complexes.

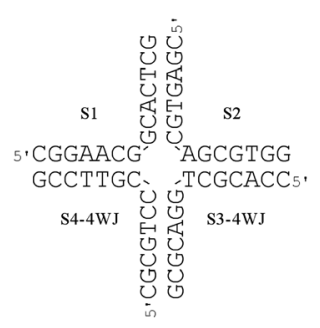

Fig. 11 The sequences of the oligonucleotides used to form the 4WJ. 
Table 3 Effect of flexicates on thermal stability of a $4 \mathrm{WJ}\left(T_{\mathrm{m}}=42.4^{\circ} \mathrm{C}\right)$ at $1: 1$ and $2: 1$ (flexicate : 4WJ) ratios

\begin{tabular}{lcc}
\hline Flexicate & $\begin{array}{l}\Delta T_{\mathrm{m}}\left({ }^{\circ} \mathrm{C}\right) \\
\text { of } 4 \mathrm{WJ} \text { at } 1: 1\end{array}$ & $\begin{array}{l}\Delta T_{\mathrm{m}}\left({ }^{\circ} \mathrm{C}\right) \\
\text { of } 4 \mathrm{WJ} \text { at } 2: 1\end{array}$ \\
\hline$\Lambda-\left[\mathrm{Fe}_{2} \mathbf{L}^{\mathbf{1 a}}{ }_{3}\right] \mathrm{Cl}_{4}$ & 6.7 & 9.7 \\
$\Delta-\left[\mathrm{Fe}_{2} \mathbf{L}^{1 \mathbf{a}}{ }_{3}\right] \mathrm{Cl}_{4}$ & 5.8 & 6.5 \\
$\Lambda-\left[\mathrm{Fe}_{2} \mathbf{L}^{2 \mathbf{a}}{ }_{3}\right] \mathrm{Cl}_{4}$ & -1.5 & -1.5 \\
$\Delta-\left[\mathrm{Fe}_{2} \mathbf{L}^{2 \mathbf{a}}{ }_{3}\right] \mathrm{Cl}_{4}$ & -1.4 & -1.4 \\
$\Lambda-\left[\mathrm{Fe}_{2} \mathbf{L}^{2 \mathbf{b}}{ }_{3}\right] \mathrm{Cl}_{4}$ & 0.0 & 0.2 \\
$\Delta-\left[\mathrm{Fe}_{2} \mathbf{L}_{3}^{2 \mathbf{b}}\right] \mathrm{Cl}_{4}$ & 0.5 & 1.0 \\
\hline
\end{tabular}

\section{Oligonucleotide duplexes with bulges}

Oligonucleotide duplexes with bulges occur when one or more of the bases on one of the strands have no base(s) on the complementary strand to form a base-pair with. Bulge sites in DNA have been shown to bind some proteins more strongly than standard duplex $\mathrm{DNA}^{59}$ and therefore are of significant interest as targets for novel drugs, ${ }^{\mathbf{6 0 , 6 1}}$ particularly in the context of peptidomimetic helices. The thermal stabilities of the oligonucleotide duplexes containing three-, two- and oneadenine bulges (A3-A1) [Fig. 12(a-c)] in the presence of the flexicates were analysed. The melting temperature of the duplexes depends on the size of the bulge, increasing from $35.2{ }^{\circ} \mathrm{C}$ (A3) to $38.7{ }^{\circ} \mathrm{C}$ (A2) to $45.0^{\circ} \mathrm{C}$ (A1) as the number of unpaired adenines in the bulge decreases. The same duplex without a bulge was also investigated as a control and has a melting temperature $54.9{ }^{\circ} \mathrm{C}$. The results are listed in Table 4 and show that only the $\Delta_{\mathrm{Fe}} / \Lambda_{\mathrm{Fe}}-\left[\mathrm{Fe}_{2} \mathbf{L}^{\mathbf{1 a}}{ }_{3}\right] \mathrm{Cl}_{4}$ flexicates have positive impacts on the thermal stability.

With the duplexes containing A3 and A2 bulges, the stabilising effect of the flexicates decreases with the size of the bulge. The thermal stability of these duplexes is further increased when the flexicate : duplex ratio is increased from $1: 1$ to $2: 1$, but the increase is only relatively small $\left(1-2^{\circ}\right)$. This is consistent with a single dominant binding site for the flexicates on these bulges with up-take slightly higher at the increased 2:1 concentration. In addition, there are no significant differences between enantiomers.

The effect of $\Delta_{\mathrm{Fe}} / \Lambda_{\mathrm{Fe}}-\left[\mathrm{Fe}_{2} \mathbf{L}^{\mathbf{1 a}}{ }_{3}\right] \mathrm{Cl}_{4}$ on the thermal stability of the duplex containing the A1 bulge shows different trends. At a 1:1 flexicate: duplex ratio the increase in melting

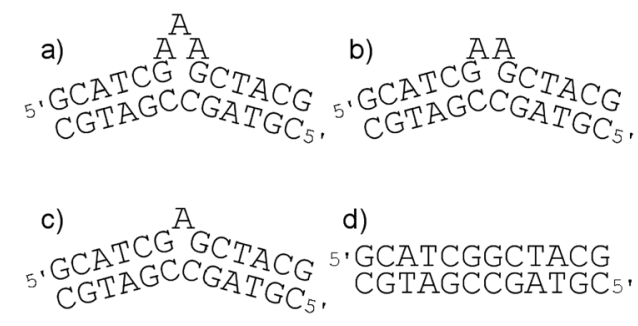

Fig. $12(\mathrm{a}-\mathrm{c})$ The sequences of the oligonucleotide duplexes containing a three-, two- and one-adenine bulge, respectively. (d) The corresponding duplex used as a control.
Table 4 Effect of the flexicates on the thermal stability of duplexes with triple-, double-, single- and no-adenine bulges at $1: 1$ and $2: 1$ (flexicate: duplex) ratios $^{a}$

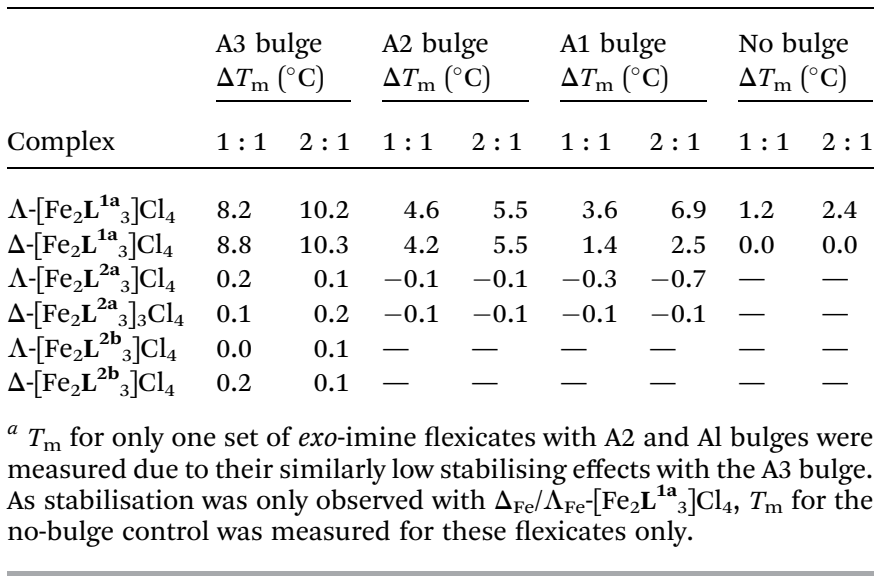

temperature is relatively small, however on increasing this ratio to $2: 1$ the $\Delta T_{\mathrm{m}}$ approximately doubles, suggesting at least two binding sites are present per duplex. This indicates a different binding mode of $\Delta_{\mathrm{Fe}} / \Lambda_{\mathrm{Fe}}-\left[\mathrm{Fe}_{2} \mathbf{L}_{3}^{\mathbf{1 a}}\right] \mathrm{Cl}_{4}$ to the A1 bulge than to the A2 and A3 bulges. Furthermore, enantiomeric differences are observed with the A1 bulge. The $\Lambda_{\mathrm{Fe}}$ enantiomer has the greater stabilising effect on the A1 bulge, with $\Delta T_{\mathrm{m}}$ more than twice that observed for the $\Delta \mathrm{Fe}$ enantiomer.

\section{H2AX expression analysis}

We noted earlier that in contrast to DNA cleavage agents and "alkylators" (including cisplatin), groove-binders reversibly form non-covalent bonds such as those indicated in the above studies, so it is of interest in terms of the mechanism of action in cells to study the extent of DNA damage. H2AX is a histone which plays a key role in the repair of damaged $\mathrm{DNA}^{62-65}$ and its expression is a useful marker for several types of DNA damage. ${ }^{66}$ We selected the cell line HCT116 $\mathrm{p}^{+/+}$for this study since it is sensitive to all the flexicates.

HCT116 p53 ${ }^{+/+}$cells $\left(5 \times 10^{5}\right.$ cells in $10 \mathrm{ml}$ RPMI medium $)$ were incubated with $10 \mu \mathrm{M}$ of each flexicate for $24 \mathrm{~h}$ (a dose that kills 55 to $72 \%$ of cells) under appropriate conditions (see $\mathrm{ESI}^{\dagger}$ ). These, along with a control of untreated HCT116 p53 ${ }^{+/+}$cells were analysed using fluorescence-activated cell sorting (FACS). Fig. 13 shows that there are no significant alterations in the production of $\mathrm{H} 2 \mathrm{AX}$, indicating that no DNA damage (increase in expression) or interruption of the H2AX pathway (decrease) has occurred.

\section{Cell cycle analysis}

We further investigated mechanism of action of flexicates by assessing how they affect the population of phases of the cell cycle for HCT116 $\mathrm{p} 53^{+/+}$. Using standard methods the cells were permeabilised and treated with the fluorescent dye propidium iodide (PI) which stains DNA quantitatively. The proportion of cells in the various phases - sub $G_{1}$ 


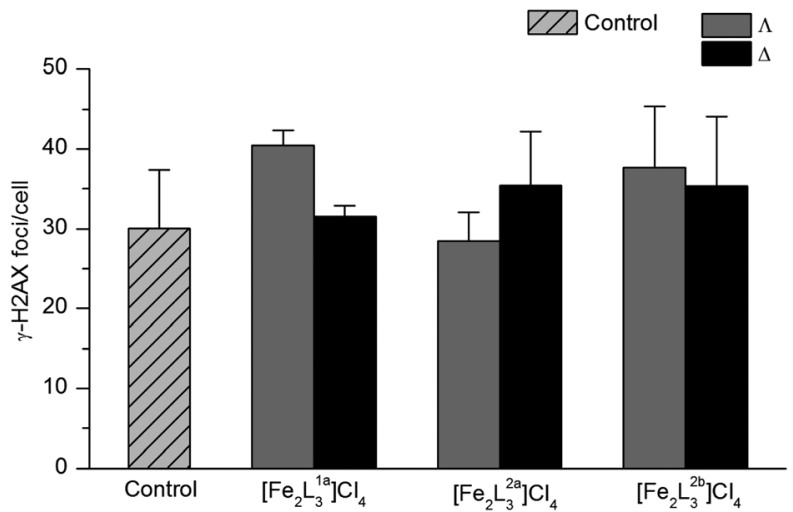

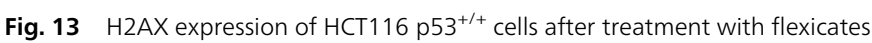
$(10 \mu \mathrm{M})$ for $24 \mathrm{~h}$, and untreated cells (control).

(apoptotic ${ }^{67}$ ), $\mathrm{G}_{1}$ (increase in size in readiness for DNA replication), $\mathrm{S}$ (DNA synthesis), $\mathrm{G}_{2}$ (preparation for mitosis) and M (mitosis) - were determined by fluorescence via FACS analysis as a result of the differing amounts of DNA in the cells (see ESI†).

As can be seen in Fig. 14, $\left[\mathrm{Fe}_{2} \mathbf{L}^{\mathbf{1 a}}{ }_{3}\right] \mathrm{Cl}_{4}$ flexicates show a dramatic increase in the proportion of cells in $G_{2} / M$ phase compared to the control (from $c a 20$ to $40 \%$ of cells); such arresting of cell growth at this phase is likely to be a significant factor in the mechanism of action. As in the cell-free DNA binding studies, the $\Lambda_{\mathrm{Fe}}$ enantiomer has the strongest effect of all compounds tested. Interestingly $\left[\mathrm{Fe}_{2} \mathbf{L}^{2 \mathbf{a}-\mathbf{b}}{ }_{3}\right] \mathrm{Cl}_{4}$ flexicates did not show a significant increase in the $G_{2} / M$ phase, indicating a different mechanism. Fig. 14 also shows a very pronounced increase in population of sub $\mathrm{G}_{1}$ cells, from $4 \%$ in the control to between 13 and $30 \%$, the latter being again for $\Lambda_{\mathrm{Fe}}\left[\mathrm{Fe}_{2} \mathbf{L}^{\mathbf{1 a}}{ }_{3}\right] \mathrm{Cl}_{4}$. Cells in the sub $\mathrm{G}_{1}$ phase are considered apoptotic ${ }^{67,68}$ and this data is thus consistent with flexicates inducing programmed cell death. Apoptosis induced by $\left[\mathrm{Fe}_{2} \mathbf{L}^{2 \mathbf{a}-\mathbf{b}}{ }_{3}\right] \mathrm{Cl}_{4}$ flexicates varies little between enantiomers; this is consistent with the chemosensitivity data reported in this cell line.

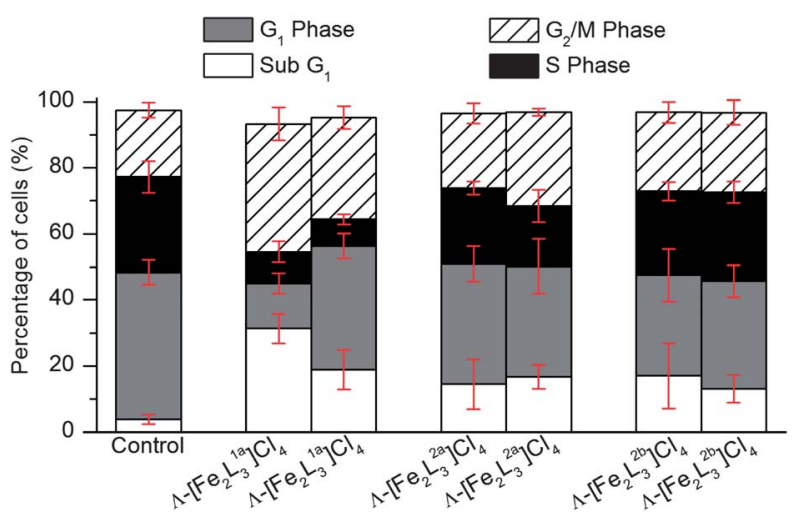

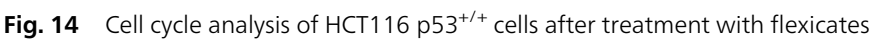
$(10 \mu \mathrm{M})$ for $24 \mathrm{~h}$, and untreated cells (control).

\section{Conclusions}

We have shown that while the flexicate enantiomers based on $\mathbf{L}^{\mathbf{1 a}}$ have comparable activity to cisplatin against MCF7 (human breast adenocarcinoma) and A2780 (human ovarian carcinoma) they are $c a$ five times more potent than cisplatin against A2780cis. For $\mathbf{L}^{2 \mathbf{a} / \mathbf{b}}$ complexes the trend is reversed and A2780cis is rather resistant to $\mathbf{L}^{2 \mathbf{2} / \mathbf{b}}$. The human colon carcinoma cell line HCT116 $\mathrm{p}^{2} 3^{+/+}$is very sensitive to all the compounds, giving $\mathrm{IC}_{50}$ values in the $\mathrm{nM}$ range, substantially more potent than cisplatin. For some flexicates the range of sensitivity is an order of magnitude or greater, indicating very promising selectively.

The $\mathbf{L}^{1 \mathbf{a}}$ flexicates are very good DNA binders and induce tertiary structural changes of the DNA as seen by AFM and correlated with solution spectroscopic techniques. The location of binding in the major groove is supported by the observation of nucleotide sequence selectivity according to DNase I footprinting. The overall picture is that the degree of DNA distortion falls in the order $\mathbf{L}^{\mathbf{1 a}}>\mathbf{L}^{\mathbf{2 a}}>\mathbf{L}^{\mathbf{2 b}}$. Given the very similar dimensions of all the complexes we suggest that this may be a function of flexibility; the linker units in $\mathbf{L}^{\mathbf{1 a}}$ are much more rigid than those in $\mathbf{L}^{2 \mathbf{2} / \mathbf{b}}$. Also, while the $\mathbf{L}^{\mathbf{1 a}}$ complexes cause formation of loops and close strand contacts, with intramolecular coiling and intermolecular aggregation at higher loading the $\mathbf{L}^{\mathbf{2 a}}$ complexes require substantially higher concentrations before tight coiling of two individual DNA strands was observed.

Binding of the flexicates to various other chemotherapeutic drug targets (3WJs, 4WJs and oligonucleotide duplexes with bulges) also follows the trend $\mathbf{L}^{1 \mathbf{a}} \gg \mathbf{L}^{2 \mathbf{a}}>\mathbf{L}^{2 \mathbf{b}}$. Fascinatingly, only the $\Lambda$ isomer of $\left[\mathrm{Fe}_{2} \mathbf{L}^{1 \mathbf{a}}{ }_{3}\right] \mathrm{Cl}_{4}$ stabilised T-shaped 3WJs during gel electrophoresis indicating the importance of our approach to creating optically pure and non-racemising systems. We have also shown for the first time that the interactions (binding strength and number of binding sites) of metallo-helices with oligonucleotide duplexes with bulges are dependent on the size of the bulge. This suggests that different sized bulges may be targeted by changing flexicate dimensions; something that is almost uniquely available from our approach to metallo-helix design. It is possible for example to design more or less flexible, longer or fatter, or differently functionalised analogues; this will feature in future reports aimed at further probing the existing correlation between metallohelixDNA interactions and cytotoxic action.

The H2AX expression data for all compounds in the study indicate that if reversible DNA major groove binding is involved in the mode of action, it does not cause DNA lesions; the chemosensitivity is not caused by DNA damage. The cell cycle analysis in HCT116 $\mathrm{p} 53^{+/+}$cells nevertheless shows dramatic changes in cell-cycle population and that the compounds, particularly the strongest DNA binders, induce apoptosis.

Taken together, the trends in the cytotoxicity data, the dramatically different abilities to bind DNA motifs and the cell cycle analysis suggest that the biological targets of $\left[\mathrm{Fe}_{2} \mathbf{L}^{\mathbf{1 a}}{ }_{3}\right] \mathrm{Cl}_{4}$ and $\left[\mathrm{Fe}_{2} \mathbf{L}^{\mathbf{2 a} / \mathbf{b}}{ }_{3}\right] \mathrm{Cl}_{4}$ are different. The potency of $\left[\mathrm{Fe}_{2} \mathbf{L}^{\mathbf{1 a}}{ }_{3}\right] \mathrm{Cl}_{4}$ against cisplatin resistant A2780cis and its ability to strongly and selectively bind DNA suggests the involvement of such an event in the mechanism. We also note that the flexible 
systems $\mathbf{L}^{\mathbf{2 a} / \mathbf{b}}$ are based on a pyridine analogue of the antimicrobial/antiparasitic agent pentamidine, ${ }^{69}$ which is a potent minor groove binder ${ }^{70}$ and has been proposed as an antitumor drug. ${ }^{71}$ The data here do not exclude the possibility that the assemblies $\left[\mathrm{Fe}_{2} \mathbf{L}_{3}{ }^{2 \mathbf{a} / \mathbf{b}}\right]^{4+}$ are acting as vectors for delivery of a ligand $\mathbf{L}^{2}$ or ligand fragments that otherwise have insufficient solubility for cancer cell-line testing. Nevertheless, we know that the mechanism of action of $\left[\mathrm{Fe}_{2} \mathbf{L}^{2 \mathbf{a} / \mathbf{b}}\right]^{4+}$ does not involve DNA binding or significant DNA damage, and the observed differences in chemosensitivity for particularly the $\mathbf{L}^{2 a}$ compounds probably does not arise from differential DNA binding ability.

These anticancer and preliminary mechanistic results provide a case for further investigating derivatives, both as $\alpha$-helix mimetic groove binders and pro-drugs, depending on the detail of the metallo-helix design.

\section{Acknowledgements}

This work was supported by: EPSRC; the University of Warwick; the Czech Science Foundation (Grant P205/11/0856) and the Academy of Sciences of the Czech Republic (Grant M200041201). The authors also acknowledge that their participation in the EU COST Action CM1105 enabled them to exchange regularly the most recent ideas in the field of metallodrugs with several European colleagues.

\section{Notes and references}

\$ Correspondingly, and because some flexicates are optically and stereochemically pure but heterohelical (the sense of helicity is not the same throughout the molecule), we use the absolute configuration descriptors at each metal ( $\Delta$ or $\Lambda$ ) rather than the helicity ( $\mathrm{P}$ or $\mathrm{M}$ ). The $\Delta$ and $\Lambda$ flexicates have local $\mathrm{P}$ and $\mathrm{M}$ helicity respectively.

1 D. Fu, J. A. Calvo and L. D. Samson, Nat. Rev. Cancer, 2012, 12, 104-120.

2 Z. H. Siddik, Oncogene, 2003, 22, 7265-7279.

3 P. L. Hamilton and D. P. Arya, Nat. Prod. Rep., 2012, 29, 134143.

4 G. S. Khan, A. Shah, R. Zia-ur-Rehman and D. Barker, J. Photochem. Photobiol., B, 2012, 115, 105-118.

5 T. W. Hambley, Dalton Trans., 2007, 4929-4937.

6 T. W. Hambley, Science, 2007, 318, 1392-1393.

7 Y. Jung and S. J. Lippard, Chem. Rev., 2007, 107, 1387-1407.

8 D. Wang and S. J. Lippard, Nat. Rev. Drug Discovery, 2005, 4, 307-320.

9 L. Kelland, Nat. Rev. Cancer, 2007, 7, 573-584.

10 M. R. Gill and J. A. Thomas, Chem. Soc. Rev., 2012, 41, 31793192.

11 J. K. Barton, E. D. Olmon and P. A. Sontz, Coord. Chem. Rev., 2011, 255, 619-634.

12 S. Blanck, J. Maksimoska, J. Baumeister, K. Harms, R. Marmorstein and E. Meggers, Angew. Chem., Int. Ed., 2012, 51, 5244-5246.

13 K. J. Kilpin and P. J. Dyson, Chem. Sci., 2013, 4, 1410-1419.

14 J. M. Lehn, A. Rigault, J. Siegel, J. Harrowfield, B. Chevrier and D. Moras, Proc. Natl. Acad. Sci. U. S. A., 1987, 84, 25652569.
15 C. Piguet, M. Borkovec, J. Hamacek and K. Zeckert, Coord. Chem. Rev., 2005, 249, 705-726.

16 M. Albrecht, Chem. Rev., 2001, 101, 3457-3498.

17 M. J. Hannon and L. J. Childs, Supramol. Chem., 2004, 16, 7-22.

18 D. L. Caulder and K. N. Raymond, Acc. Chem. Res., 1999, 32, 975-982.

19 S. E. Howson and P. Scott, Dalton Trans., 2011, 40, 1026810277.

20 M. J. Hannon, C. L. Painting, A. Jackson, J. Hamblin and W. Errington, Chem. Commun., 1997, 1807-1808.

21 J. Xu, T. N. Parac and K. N. Raymond, Angew. Chem., Int. Ed., 1999, 38, 2878-2882.

22 M. Elhabiri, R. Scopelliti, J.-C. G. Bünzli and C. Piguet, J. Am. Chem. Soc., 1999, 121, 10747-10762.

23 N. André, T. B. Jensen, R. Scopelliti, D. Imbert, M. Elhabiri, G. Hopfgartner, C. Piguet and J.-C. G. Bünzli, Inorg. Chem., 2004, 43, 515-529.

24 J.-C. G. Bünzli, Acc. Chem. Res., 2006, 39, 53-61.

25 A.-S. Chauvin, S. Comby, B. Song, C. D. B. Vandevyver, F. Thomas and J.-C. G. Bünzli, Chem.-Eur. J., 2007, 13, 9515-9526.

26 C. D. B. Vandevyver, A.-S. Chauvin, S. Comby and J.-C. G. Bünzli, Chem. Commun., 2007, 1716-1718.

27 J.-C. G. Bünzli, A.-S. Chauvin, C. D. B. Vandevyver, S. Bo and S. Comby, Ann. N.Y. Acad. Sci., 2008, 1130, 97-105.

28 V. Fernández-Moreira, B. Song, V. Sivagnanam, A.-S. Chauvin, C. D. B. Vandevyver, M. Gijs, I. Hemmilä, H.-A. Lehr and J.-C. G. Bünzli, Analyst, 2010, 135, 42-52.

29 J.-C. G. Bünzli, C. D. B. Vandevyver, A.-S. Chauvin, M. Gijs and A.-A. Lehr, CHIMIA International Journal for Chemistry, 2011, 65, 361.

30 J. M. C. A. Kerckhoffs, J. C. Peberdy, I. Meistermann, L. J. Childs, C. J. Isaac, C. R. Pearmund, V. Reudegger, S. Khalid, N. W. Alcock, M. J. Hannon and A. Rodger, Dalton Trans., 2007, 734-742.

31 J. Malina, M. J. Hannon and V. Brabec, Nucleic Acids Res., 2008, 36, 3630-3638.

32 M. J. Hannon, V. Moreno, M. J. Prieto, E. Moldrheim, E. Sletten, I. Meistermann, C. J. Isaac, K. J. Sanders and A. Rodger, Angew. Chem., Int. Ed., 2001, 40, 879-884.

33 G. I. Pascu, A. C. G. Hotze, C. Sanchez-Cano, B. M. Kariuki and M. J. Hannon, Angew. Chem., Int. Ed., 2007, 46, 43744378.

34 A. C. G. Hotze, N. J. Hodges, R. E. Hayden, C. Sanchez-Cano, C. Paines, N. Male, M.-K. Tse, C. M. Bunce, J. K. Chipman and M. J. Hannon, Chem. Biol., 2008, 15, 1258-1267.

35 A. D. Richards, A. Rodger, M. J. Hannon and A. Bolhuis, Int. J. Antimicrob. Agents, 2009, 33, 469-472.

36 H. Yu, X. Wang, M. Fu, J. Ren and X. Qu, Nucleic Acids Res., 2008, 36, 5695-5703.

37 H. Yu, C. Zhao, Y. Chen, M. Fu, J. Ren and X. Qu, J. Med. Chem., 2009, 53, 492-498.

38 C. Zhao, J. Geng, L. Feng, J. Ren and X. Qu, Chem.-Eur. J., 2011, 17, 8209-8215.

39 H. Yu, M. Li, G. Liu, J. Geng, J. Wang, J. Ren, C. Zhao and X. Qu, Chem. Sci., 2012, 3, 3145-3153. 
40 L. Cardo, V. Sadovnikova, S. Phongtongpasuk, N. J. Hodges and M. J. Hannon, Chem. Commun., 2011, 47, 65756577.

41 S. E. Howson, L. E. N. Allan, N. P. Chmel, G. J. Clarkson, R. van Gorkum and P. Scott, Chem. Commun., 2009, 17271729.

42 S. E. Howson, L. E. N. Allan, N. P. Chmel, G. J. Clarkson, R. J. Deeth, A. D. Faulkner, D. H. Simpson and P. Scott, Dalton Trans., 2011, 40, 10416-10433.

43 S. E. Howson, A. Bolhuis, V. Brabec, G. J. Clarkson, J. Malina, A. Rodger and P. Scott, Nat. Chem., 2012, 4, 31-36.

44 S. E. Howson, G. J. Clarkson, A. D. Faulkner, R. A. Kaner, M. J. Whitmore and P. Scott, Dalton Trans., 2013, DOI: 10.1039/c3dt51725j.

45 R. Palchaudhuri and P. J. Hergenrother, Curr. Opin. Biotechnol, 2007, 18, 497-503.

46 I. Meistermann, V. Moreno, M. J. Prieto, E. Moldrheim, E. Sletten, S. Khalid, P. M. Rodger, J. C. Peberdy, C. J. Isaac, A. Rodger and M. J. Hannon, Proc. Natl. Acad. Sci. U. S. A., 2002, 99, 5069-5074.

47 A. Rodger, K. J. Sanders, M. J. Hannon, I. Meistermann, A. Parkinson, D. S. Vidler and I. S. Haworth, Chirality, 2000, 12, 221-236.

48 L. Fairall and D. Rhodes, Nucleic Acids Res., 1992, 20, 47274731.

49 in Methods in molecular biology - Drug-DNA interaction protocols, ed. K. R. Fox, Humana Press, Totowa, New Jersey, 1997.

50 J. Malina, M. J. Hannon and V. Brabec, Chem.-Eur. J., 2008, 14, 10408-10414.

51 N. B. Leontis, W. Kwok and J. S. Newman, Nucleic Acids Res., 1991, 19, 759-766.

52 M. R. Singleton, S. Scaife and D. B. Wigley, Cell, 2001, 107, 79-89.

53 A. Nikulin, A. Serganov, E. Ennifar, S. Tishchenko, N. Nevskaya, W. Shepard, C. Portier, M. Garber, B. Ehresmann, C. Ehresmann, S. Nikonov and P. Dumas, Nat. Struct. Biol., 2000, 7, 273-277.

54 A. Oleksi, A. G. Blanco, R. Boer, I. Usón, J. Aymamí, A. Rodger, M. J. Hannon and M. Coll, Angew. Chem., Int. Ed., 2006, 45, 1227-1231.
55 J. Malina, M. J. Hannon and V. Brabec, Chem.-Eur. J., 2007, 13, 3871-3877.

56 J. L. Kadrmas, A. J. Ravin and N. B. Leontis, Nucleic Acids Res., 1995, 23, 2212-2222.

57 R. Holliday, Genet. Res., 1964, 5, 282-304.

58 M. Culyba, Y. Hwang, S. Attar, P. B. Madrid, J. Bupp, D. Huryn, L. Sanchez, J. Grobler, M. D. Miller and F. D. Bushman, Nucleic Acids Res., 2012, 40, e124.

59 K. Nakatani, S. Sando and I. Saito, J. Am. Chem. Soc., 2000, 122, 2172-2177.

60 L. Guan and M. D. Disney, ACS Chem. Biol., 2011, 7, 73-86.

61 A. Davidson, T. C. Leeper, Z. Athanassiou, K. PatoraKomisarska, J. Karn, J. A. Robinson and G. Varani, Proc. Natl. Acad. Sci. U. S. A., 2009, 106, 11931-11936.

62 J. Kobayashi, J. Radiat. Res., 2004, 45, 473-478.

63 in Molecular Determinants of Radiation Response, ed. T. L. DeWeese and M. Laiho, Springer New York, New York, 2011. 64 W. M. Bonner, C. E. Redon, J. S. Dickey, A. J. Nakamura, O. A. Sedelnikova, S. Solier and Y. Pommier, Nat. Rev. Cancer, 2008, 8, 957-967.

65 A. Celeste, S. Petersen, P. J. Romanienko, O. FernandezCapetillo, H. T. Chen, O. A. Sedelnikova, B. Reina-SanMartin, V. Coppola, E. Meffre, M. J. Difilippantonio, C. Redon, D. R. Pilch, A. Olaru, M. Eckhaus, R. D. Camerini-Otero, L. Tessarollo, F. Livak, K. Manova, W. M. Bonner, M. C. Nussenzweig and A. Nussenzweig, Science, 2002, 296, 922-927.

66 L. J. Kuo and L.-X. YANG, In Vivo, 2008, 22, 305-309.

67 M. Kajstura, H. D. Halicka, J. Pryjma and Z. Darzynkiewicz, Cytometry, Part A, 2007, 71, 125-131.

68 I. Nicoletti, G. Migliorati, M. C. Pagliacci, F. Grignani and C. Riccardi, J. Immunol. Methods, 1991, 139, 271-279.

69 S. M. Bakunova, S. A. Bakunov, T. Wenzler, T. Barszcz, K. A. Werbovetz, R. Brun and R. R. Tidwell, J. Med. Chem., 2009, 52, 4657-4667.

70 P. G. Baraldi, A. Bovero, F. Fruttarolo, D. Preti, M. A. Tabrizi, M. G. Pavani and R. Romagnoli, Med. Res. Rev., 2004, 24, 475-528.

71 M. S. Lee, L. Johansen, Y. Zhang, A. Wilson, M. Keegan, W. Avery, P. Elliott, A. A. Borisy and C. T. Keith, Cancer Res., 2007, 67, 11359-11367. 